\title{
Polymorphism of Thyroid Hormones Receptor, Angiotensin- Converting Enzyme, and High Blood Pressure in Childbearing Age Women with Hyperthyroidism
}

\author{
R. Agus Wibowo ${ }^{1,2}$, , Pramudji Hastuti ${ }^{3 *(D)}$, Vinayanti Susanti ${ }^{4}$ (D) \\ ${ }^{1}$ Student of Doctorate Program, Faculty of Medicine, Public Health and Nursing, Universitas Gadjah Mada Jogjakarta, Yogyakarta, \\ Indonesia; ${ }^{2}$ National Institute Health Research and Development, Indonesia Ministry of Health; ${ }^{3}$ Department of Biochemistry \\ Faculty of Medicine, Public Health and Nursing, Universitas Gadjah Mada Jogjakarta, Yogyakarta, Indonesia; ${ }^{4}$ Department of \\ Internal Medicine Faculty of Medicine, Public Health and Nursing Universitas Gadjah Mada Jogjakarta, Yogyakarta, Indonesia
}

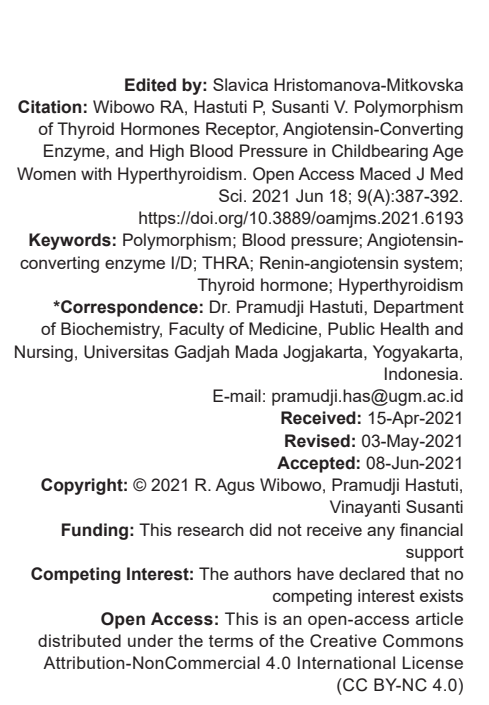

Abstract

AIM: This study aimed to investigate the association between two polymorphisms of thyroid hormone receptor and
renin-angiotensin system (THRA C/T and angiotensin-converting enzyme $(A C E) I / D$ ) genes with hypertension in childbearing age women with hypertension.

METHODS: This was a case-control study including 35 cases and 40 matched control subjects. The case group was hyperthyroid women with hypertension while the control group was hyperthyroid women with normotension. The polymorphisms were identified by a classical polymerase chain reaction.

RESULTS: The THRA C/T gene and ACE I/D polymorphisms were not associated with the hypertension while the genotype frequencies in hyperthyroid women with hypertension were as follows: CC genotype was $25.71 \%$, CT genotype was $54.29 \%$, and TT genotype was $20.00 \%$. The ACE I/D genotype frequencies in hyperthyroid women with hypertension were as follows: II genotype was $23.53 \%$, whereas in hyperthyroid women without hypertension, the I/D genotype frequencies were CC: $7.50 \%$, CT: $72.50 \%$, and TT: $20.00 \%$. There were no differences in age, thyroidstimulating hormone, FT4, systolic blood pressure (SBP), diastolic BP between subgroups in ACE I/D, and at THRA rs-939348. There was a significant difference in the levels of FT4 concentrations in THRA rs-939348. Hypertension groups have higher SBP than controls. Genotype II had higher SBP but it was not statistically significant, while individuals with allele I had SBP higher than D allele.

CONCLUSIONS: The I allele of the ACE gene is involved in susceptibility to hypertension and polymorphism in THRA increasing concentration of FT4. There was no statistically significant difference in blood pressure between hyperthyroid women with or without hypertension.

\section{Introduction}

Thyroid hormones are important hormones for normal human growth, cell development, and metabolism in the body [1], [2]. Hyperthyroidism is the symptom of an overactive thyroid gland to produce thyroid hormones. Hyperthyroidism is characterized by weight loss, exophthalmos, nervousness, hyperphagia, heat intolerance, increased pulse pressure, and tremors. Hyperthyroidism makes the thyroid gland increase production of T4 and T3 and suppresses thyroid-stimulating hormone (TSH). The most common cause of hyperthyroidism is the autoimmune disorder called Graves' disease which is more common in women than men [1].

Hyperthyroid increases blood pressure (BP). Hypertension affects women in all phases of life, with specific characteristics relating to risk factors.
Hypertension in women can occur in pregnancy, during use of contraceptives and assisted reproductive technologies, lactation, menopause, or hormone replacement therapy; hypertension often occurs in elderly women and can be related to issues of race and ethnicity [3]. Hyperthyroidism can be caused by genetic variation in the thyroid hormone receptor. Genetic predispositions of these complications of hyperthyroidism can have an obvious effect throughout the life of a patient. A few studies documented the link between THRA polymorphism rs-939348 and higher systolic BP (SBP) was a risk of hypertension [4], [5]. Another cause of hypertension is the renin-angiotensin system. It plays a major role in the homeostasis of BP. One of the enzymes of this system is the angiotensinconverting enzyme (ACE) that converts angiotensin I to angiotensin II. ACE is a peptidyl dipeptidase that releases C-terminal dipeptides from substrates [6]. $\mathrm{ACE}$ is an important regulator of $\mathrm{BP}$ and cardiovascular homeostasis. Plasma levels of ACE depend on an 
insertion/deletion (I/D) polymorphism in its gene [1]. ACE is a carboxypeptidase that plays a central role in the RAS by catalyzing the conversion of angiotensin I to vasoactive angiotensin II. Polymorphism in ACE I/D will affect the secretion of this enzyme which, in turn, affects BP [7].

This research aimed to determine the impact of hyperthyroidism in women of childbearing age with THRA C/T (rs 939348) and ACE I/D genetic polymorphism and increased BP.

\section{Materials and Methods}

This was a cross-sectional observational study. The early study was conducted on 75 childbearing age women chosen from the outpatient clinic at the Clinic Health Research and Development of Magelang Central Java. Samples were diagnosed with hyperthyroidism. Participants ranged in age from 16 to 65 years and come from iodine deficiency disorder replete area. Samples were collected during the period from January 2020 to December 2020.

The whole process strictly followed the guidelines and regulations set by the Helsinki Declaration of 1975, with all amendments and revisions. The study was approved by the appropriate Institutional Ethics Committee.

\section{Blood pressure}

Systolic and diastolic BP (SBP and DBP) measurements, using the auscultation method, were performed on the left upper arm in sitting position after resting for at least 15 min using a sphygmomanometer. Hypertension was defined as mean SBP $\geq 140 \mathrm{mmHg}$ and/or mean DBP $\geq 90 \mathrm{mmHg}$ according to the American Heart Association recommendations.

\section{Sample collection and handling}

Fasting blood samples were collected from patients who matched the study criteria. Blood $(5 \mathrm{~mL})$ was withdrawn and distributed into plain tubes $(3 \mathrm{~mL})$ and EDTA tubes $(2 \mathrm{~mL})$. The blood sample in the plain tube was centrifuged after $30 \mathrm{~min}$ of sampling and serum was isolated and stored at $-20^{\circ} \mathrm{C}$ and sent to the laboratory for biochemical analysis. Assays include TSH, fT4. Thyroid hormone levels were measured by enzymelinked immunosorbent assay (ELISA) (Human.de, Germany). Samples were assayed in duplicate and the mean of the paired results was determined. EDTA tubes were stored properly at $-20^{\circ} \mathrm{C}$ for molecular analysis.

\section{Molecular biology techniques}

Genomic DNA was extracted and purified from whole peripheral blood samples using GeneJet DNA isolation kit (Thermo Fisher Scientific). DNA stored at $-80^{\circ} \mathrm{C}$ in aliquots until required. Amplification of the ACE gene was done by polymerase chain reaction (PCR) using PCR Master Mix (Thermo Fisher Scientific) and Veriti Thermal Cycler from Applied Biosystem.

\section{Variation on ACE I/D}

The sequence of primers used for amplification of ACE was 5'-CTG GAG ACC ACT CCC ATC CTT TCT-3' (forward) and 5'-GAT GTC GCC ATC ACA TTC GT CAG AT-3' (reverse). Amplification of the I allele is sometimes suppressed in ID genotype samples giving rise to mistyping of ID as DD in approximately $5 \%$ of cases. To avoid such mistyping, samples of the DD genotype were subjected to a second independent PCR with primers that recognize an insertion-specific sequence: 5'-TGG GAC CAC AGC GCC CGC CAC TAC-3' (forward) and 5'-TCG CCA GCC CTC CCA TGC CCA TAA-3' (reverse). Electrophoresis was then performed on $2 \%$ agarose gels stained with SYBR Safe and the electrophoretic products were visualized using ultraviolet light transillumination. The PCR product was either $490 \mathrm{bp}$ insertion (I allele) or $190 \mathrm{bp}$ deletion (D allele). The second PCR with the insertion-specific primers yielded a $335 \mathrm{bp}$ DNA product in the presence of the I allele and no product for homozygous DD samples (Figure 1).

\section{Variation on THRA rs 939348}

The genomic DNA was amplified using the following steps: Denaturation of double-stranded genomic DNA at $94^{\circ} \mathrm{C}$ for $5 \mathrm{~min}$, DNA amplification using 30 cycles. Each cycle consisted of denaturation at $94^{\circ} \mathrm{C}$ for $30 \mathrm{~s}$, annealing at $54^{\circ} \mathrm{C}$ for $30 \mathrm{~s}$, extension at $72^{\circ} \mathrm{C}$ for $40 \mathrm{~s}$, final elongation at $72^{\circ} \mathrm{C}$ for $7 \mathrm{~min}$, and ending reaction at $4^{\circ} \mathrm{C}$. For single-nucleotide polymorphism (SNP) rs939348, e PCR primers, foward:5 ${ }^{`}$-CCT GTG TCT CCC AGC TTA GG-3`; and reverse: 5'-CCA CCA GAC TCA CAG CCT CT-3`, the PCR product was $190 \mathrm{bp}$ (size of amplified fragment), the sizes of the digested fragments of the examined SNPs were $C$ allele $190 \mathrm{~T}$ allele 48 and $142 \mathrm{bp}$. The restriction enzyme (Msel) digestion was done in $1 \mu$ containing 10 units of enzyme (Msel) with $5 \mu \mathrm{l}$ of $\times 10$ buffer and $1 \mu \mathrm{g}$ of PCR product and incubated at $37^{\circ} \mathrm{C}$ for 30 min. Restriction enzyme was obtained from Thermo Fisher Scientific. Size of restricted fragments for $C$ allele was $190 \mathrm{bp}$ and T allele was 142 and $48 \mathrm{bp}$. PCR products and digested fragments were detected using electrophoresis on $2 \%$ agarose (Figure 1). 


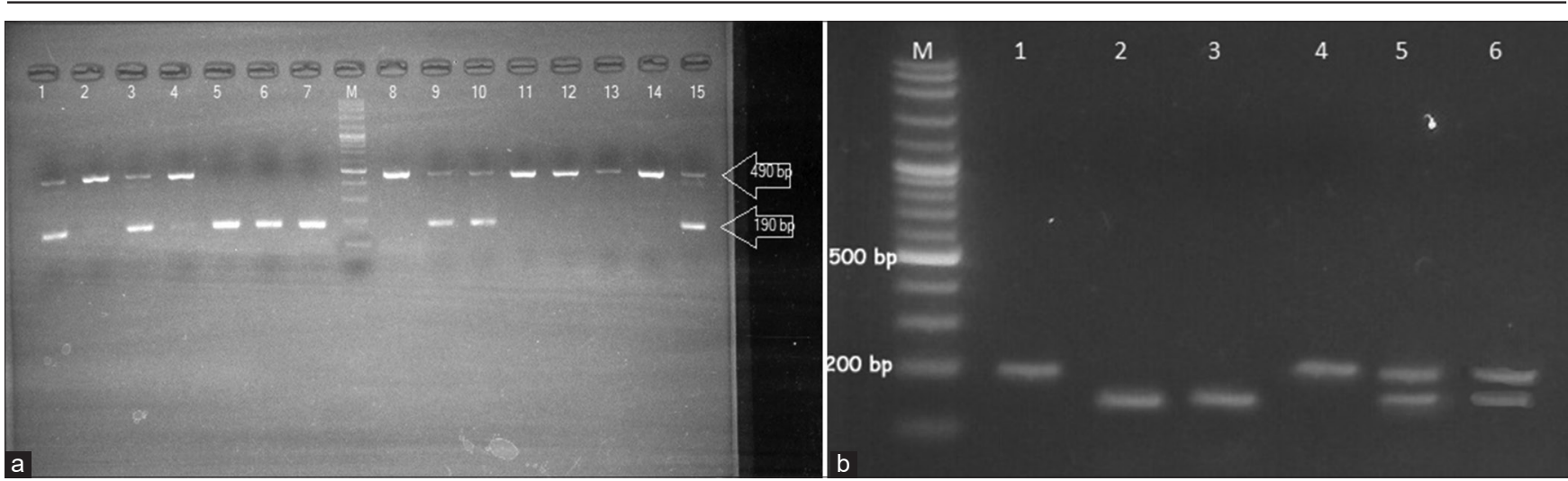

Figure 1: (a). PCR products of the ACE gene in 2\% agarose gel. Size of I allele $490 \mathrm{bp}$ and D allele: $190 \mathrm{bp}$. M; DNA ladder/marker. Lane nos. 1 , 3, 4, 9, 10, 15, and 16 containing samples show the ID genotype. Lane nos. 2, 8, 11, 12, 13, 14, and 24 containing samples show the II genotype. Lane nos. 5, 6, and 7 containing samples show the DD genotype (b) restriction fragment products of THRA rs 939348 with endonuclease restriction MSel size of C allele - 190 bp and T allele - 142 and 48 bp; M: Marker; line 1,4: Homozygote CC; line 2,3: Homozygote TT; lane 5,6: Heterozygote

\section{Statistical analysis}

The results were presented as means \pm standard deviation. The Hardy-Weinberg equilibrium was tested using $x^{2}$ to determine allelic frequency. Analysis of variance was used to assess the association between genotypes and baseline characteristics. The $x^{2}$ test was done for ascertaining the homogeneity of proportions and to determine the significance of polymorphism and risk factors.

\section{Results}

A total of 75 hyperthyroid women childbearing age were enrolled in the study. Thirty-five individuals were hyperthyroid with hypertension (case) and 40 individuals were hyperthyroid with normotension. Subjects expressed as hyperthyroidism if level TSH $<0.3 \mu \mathrm{lU} / \mathrm{mL}$ and FT4 $>2.0$ $\mathrm{ng} / \mathrm{dL}$. The Level of TSH and FT4 determined by ELISA.

Characteristically, there was no statistically significant difference between the hyperthyroid group with hypertension and hyperthyroid-normotension in the parameters of age, SBP, DBP, TSH, and FT4 ( $p>$ 0.05 ) but in SBP, the case group had a higher value even though it was not statistically significant (Table 1).

Table 1: Demographic, biochemical, and hormonal characteristics of the studied group

\begin{tabular}{lllll}
\hline Characteristic & Control & Hypertension & All & p value \\
\hline Age & $40.24 \pm 13.298$ & $42.09 \pm 12.206$ & $41.08 \pm 12.746$ & 0.671 \\
SBP & $122.45 \pm 6.809$ & $148.85 \pm 14.750$ & $136.14 \pm 18.974$ & 0.070 \\
DBP & $72.02 \pm 7.993$ & $79.97 \pm 10.572$ & $75.65 \pm 9.636$ & 0.157 \\
TSH & $0.06 \pm 0.035$ & $0.05 \pm 0.0179$ & $0.05 \pm 0.028$ & 0.219 \\
fT4 & $4.98 \pm 2.351$ & $5.01 \pm 1.601$ & $5.03 \pm 2.037$ & 0.178 \\
\hline SBP: Systolic blood pressure, DBP: Diastolic blood pressure, TSH: Thyroid-stimulating hormones; \\
FT4: Free thyroxin.
\end{tabular}

Further, comparison polymorphism in THRA rs 939348 and ACE I/D was performed on the homozygous and heterozygous of subject between subjects. No statistically significant different was found in THRA rs 939348 and $A C E$ I/D allele and genotype frequencies with the subgroup $(p>0.05)$. The distribution of genotypes and alleles based on the Hardy-Weinberg equilibrium shows that in THRA rs 939348 is in accordance with the HWE rule $(p=0.544)$ while in ACE I/D, it is not in accordance with HWE $(p=0.019)$ (Table 2).

Table 2: Genotype distribution of polymorphisms genes (cases vs. controls)

\begin{tabular}{|c|c|c|c|c|c|c|}
\hline Polymorphism & Control & Hypertension & Total & $p$ value & HWE & OR $(95 \% \mathrm{Cl})$ \\
\hline \multicolumn{7}{|l|}{ THRA 939348} \\
\hline \multicolumn{7}{|l|}{ Genotype } \\
\hline $\mathrm{CC}$ & 11 & 9 & 20 & Ref & \multirow{3}{*}{0.554} & \\
\hline CT & 20 & 19 & 39 & 0.233 & & $2.800(0.501-15.659)$ \\
\hline TT & 9 & 7 & 16 & 0.782 & & $0.750(0.098-5.768)$ \\
\hline \multicolumn{7}{|l|}{ Allele } \\
\hline C & 42 & 37 & & & & \\
\hline T & 38 & 33 & & 0.222 & & $2.714(0.529-13.916)$ \\
\hline \multicolumn{7}{|l|}{ ACE I/D } \\
\hline \multicolumn{7}{|l|}{ Genotype } \\
\hline II & 3 & 10 & 13 & Ref & & \\
\hline ID & 29 & 18 & 47 & 0.236 & \multirow[t]{2}{*}{0.019} & $4.250(0.344-54.066)$ \\
\hline DD & 8 & 7 & 15 & 0.425 & & $0.286(0.12-6.914)$ \\
\hline \multicolumn{7}{|l|}{ Allele } \\
\hline 1 & 35 & 38 & & & & \\
\hline D & 55 & 32 & & 0.127 & & $6.000(0.478-75.344)$ \\
\hline
\end{tabular}

Based on the genotype distribution, it can be seen that there were no differences in age, TSH, FT4, SBP, and DBP between subgroups in ACE I/D. Likewise, at THRA rs-939348, there was no significant difference between age, TSH, SBP, and BDP, but there was a significant difference in the levels of FT4 concentrations (Table 3 ). There was no statistically significant difference between genotype TT and CC+CT with concentration of TSH ( $p>0.05)$. Table 3 shows that there were differences of SBP between II genotype and $I D+D D$, but it was not statistically significant $(p>0.05)$. The I allele contributed to the incidence of hypertension in this study compared to the $\mathrm{D}$ allele.

Table 3: Association of the ACE and THRA genotype with risk factors

\begin{tabular}{lllll}
\hline Parameter & SBP & DBP & TSH & FT4 \\
\hline Genotype ACE I/D & & & & \\
II & $149.92 \pm 24.74$ & $78.17 \pm 7.48$ & $0.06 \pm 0.01$ & $4.30 \pm 1.20$ \\
ID & $136.63 \pm 22.28$ & $75.52 \pm 10.38$ & $0.06 \pm 0.03$ & $5.33 \pm 1.72$ \\
DD & $131.73 \pm 13.24$ & $79.02 \pm 8.72$ & $0.05 \pm 0.01$ & $5.05 \pm 3.17$ \\
p value & 0.068 & 0.397 & 0.536 & 0.279 \\
Genotype THRA & & & & \\
CC & $135.66 \pm 19.34$ & $77.79 \pm 9.27$ & $0.05 \pm 0.019$ & $4.24 \pm 1.56$ \\
CT & $139.20 \pm 22.57$ & $77.88 \pm 9.99$ & $0.06 \pm 0.025$ & $5.72 \pm 2.23$ \\
TT & $137.55 \pm 23.65$ & $72.37 \pm 8.37$ & $0.07 \pm 0.044$ & $4.55 \pm 1.48$ \\
p value & 0.845 & 0.130 & 0.496 & 0.014 \\
\hline SBP: Systolic blood pressure, DBP: Diastolic blood pressure, TSH: Thyroid-stimulating hormones; \\
FT4: Free thyroxin.
\end{tabular}




\section{Discussion}

Thyroid hormones act on molecular pathways in the heart and blood vessels. Disorders of the thyroid hormones cause relevant cardiovascular disorders. Hyperthyroidism will cause several irregularities in the heart, including increased preload, high cardiac output, with increased heart rate, decreased peripheral vascular resistance, and circulating hyperdynamics [8], [9]. From the data presented, it is found that women of childbearing age have a susceptibility to suffer from hyperthyroidism which correlates with an increase in BP. Data showed that hyperthyroidism women with hypertension have SBP higher than controls although the results were not statistically significant including concentrations TSH and FT4 of both groups (Table 1).

Thyroid disease is quite common. Current estimates suggest that it affects as many as $9-15 \%$ of the adult female population and a smaller percentage of adult males. This gender-specific prevalence almost certainly results from the underlying autoimmune mechanism for the most common forms of thyroid disease, which include both Graves' and Hashimoto's diseases. However, with advancing age, especially beyond the eighth decade of life, the incidence of disease in males rises to be equal to that of females [10], [11].

As a result, the excess of thyroid hormone typically causes SBP to rise, and the increase can be quite dramatic in older patients with impaired arterial compliance as a result of atherosclerotic disease. Hyperthyroidism has been documented as a secondary cause of isolated systolic hypertension, which is the most common form of hypertension [10], [12]. Hypertension is a polygenic disease, and environmental and genetic as well as factors are together involved in the pathogenesis of hypertension. Some common gene variants have been associated with an increased susceptibility to develop high BP [13], [14], [15], [16], [17], [18], [19].

The ACE gene exists in chromosome 17q23. In accordance with the presence or absence of the $287 \mathrm{bp}$ fragment in intron 16, there is I/D polymorphism. Some studies confirmed the presence of three genotypes: Deletion homozygous genotype DD, insertion homozygous genotype II, and heterozygous genotype ID. Importantly in this research, ID and DD genotypes of the $A C E$ gene were found not to be associated with hypertension in women of childbearing age with hyperthyroidism. The previous studies on ACE ID gene polymorphism in the Indian, Malaysian, and Indonesian population showed a significant association with the DD genotype with hypertension.

In this study, genotype frequency of $A C E$ I/D was not within the HWE rule (Table 2; $p<0.05$ ). There are several factors that may influence alleles frequency balance in population, such as individual migration into or out of the population, presence of allele mutations, and absence of random marriage.
The population of a society is highly dynamic, and the occurrence of migration and contact with other populations is inevitable. An individual in the population can have more offspring than another individual, thus contributing to the disproportion of the number of alleles in later generations. In a real population, the frequency that suits the Hardy-Weinberg model of equilibrium is rarely encountered.

In our study, which included 35 patients and 40 matched controls, we observed no significant association between ACE I/D genotypes with the study group. Our result was not consistent with other research. In humans, a positive association of the $A C E$ $D$ allele has been observed in some research [17]. Results in the Burkinabe and Tunisian populations also reported strong associations between the DD genotype and the risk of hypertension in their study populations. A significant association $D$ allele with hypertension was also reported in African, Americans, Chinese, and Japanese populations [20], but not in other casecontrol studies of hypertension and this polymorphism. However, association studies between the D allele and the risk of hypertension did not find any evidence in the Italian population [21]

Different association was also shown in Chinese population, Italian, Greek, Japan, Indian, and Bangladesh [22], [23]. Different results were also showed in two studies from Australia and Pakistan that recorded the association of I allele with hypertension. The association of I allele with hypertension in the Pakistani population was attributed to limited number of individuals studied and to the presence of high levels of inbreeding [20].

Notably, the association between I/D polymorphism and hypertension is still controversial. Some studies have shown the association of ACE I/D polymorphism with essential hypertension and some studies failed to show the association. The controversy is due to the methodology, ethnicity, or inclusion criteria variances and further studies are needed to eliminate this controversy [20], [22], [23].

Another cause of hypertension is variation in the THRA gene. Various polymorphisms in THRA gene have been identified. Some research of this gene's polymorphisms found a relationship with specific diseases including hypertension and coronary heart disease. This research showed significant association of this SNP rs939348 polymorphism and SBP and the risk of hypertension, but not with coronary heart disease [5]. Individuals carrying the T allele of this SNP had higher SBP than CC individuals. In a previous study, we reported on the detection of significant and consistent associations between the minor allele $T$ of the THRA rs939348 SNP and elevated SBP in this research but the finding was not statistically significant. Consequently, this allele was also associated with higher risk of hypertension [5]. THRA rs939348 was associated with the concentration of FT4 in which 
individuals with allele $\mathrm{T}$ have higher concentration $\mathrm{FT} 4$ than $C$ allele $(p<0.05)$. Many polymorphisms in THRA that indicated resistance of thyroid hormones otherwise showed increase of FT4 or FT3 [24].

Polymorphism rs-939348 was not associated with variations of serum thyroid nor stimulating hormone (TSH) level in healthy subjects [25]. This is consistent with our result that showed no statistically significant difference between the case and control groups. Another research showed that this polymorphism was not associated with Alzheimer's disease, although subjects with the TT genotype of this SNP had a tendency to have a higher risk of developing Alzheimer's disease [25], [26]. Further, the related two polymorphic sites of the THRA gene (rs12939700 and 2390 A/G) with TSH level were investigated by Sørensen et al. in 2008 [27], and their data showed that no significant association was found.

There are very few data related to the relationship between hyperthyroidism and hypertension in Javanese ethnicity in Indonesia, especially among women of childbearing age. In theory, the occurrence of hyperthyroidism will trigger the incidence of hypertension. In addition, genetic linkages between ethnicities also affect these relationships. Different results were also possibly obtained due to limitations in this study where the data displayed were still from a preliminary study so that more samples are needed to be added to strengthen these conclusions.

\section{Conclusions}

There was a significant relationship between THRA and level concentration of FT4. This study showed no significant relationship between $A C E$ gene polymorphism I/D and hypertension in women childbearing age with hyperthyroidism. In the analysis of the ACE genotype, it can be concluded that $\mathrm{D}$ allele frequency of $A C E$ gene in women population is very low. Genotype II was a risk of hypertension in women childbearing age with hyperthyroidism.

\section{Acknowledgments}

We are grateful to Dr. Suryati Kumorowulan, Dr. Taufik Hidayat, Dr. Wayan Dani MJ, and Sri Nuryani W, clinic and laboratory staff of Magelang Health Research Development Center and all colleagues who provided technical support to the development of this paper.

\section{Authors' Contributions}

RAW and PH: Idea/concept. Design was contributed by RAW. PH and VYS: Supervision and controlling data. Data collection/processing by RAW. Analysis/interpretation was done by RAW, PH, and VYS. Revision of the article was done by RAW, PH, and VYS. All authors have read and approved the final manuscript.

\section{Ethics Approval and Informed Consent were required in our Study}

The research protocol was approved by the Research Ethical Committee of the Faculty of Medicine, Public Health and Nursing, Universitas Gadjah Mada. The research also conformed to the ethical guidelines of the Declaration of Helsinki, as revised in 2013. A written informed consent was obtained from all participants before enrollment in the study.

\section{References}

1. Heshmat $\mathrm{H}$, El Taib S. The role of endurance exercise program inhyperthyroidism in relation to ACE genotype. J Am Sci. 2013;9(2):372-6.

2. Zhang J, Lazar MA. The mechanism of action of thyroid hormones. Annu Rev Physiol. 2000;62(1):439-66. PMid:10845098

3. Wenger NK, Arnold A, Bairey Merz CN, Cooper-DeHoff RM, Ferdinand KC, Fleg JL, et al. Hypertension across a woman's life cycle. J Am Coll Cardiol. 2018;71(16):1797-813. https://doi. org/10.1016/j.jacc.2018.02.033

PMid:29673470

4. Sinha S, Kar K. Single nucleotide polymorphism of thyroid hormone receptor $\alpha$ gene can be a risk of atherogenic dyslipidemia. J Clin Diagnostic Res. 2018;12(9):BC01-4. https:// doi.org/10.7860/jcdr/2018/34904.11974

5. Goumidi L, Gauthier K, Legry V, Mayi TH, Houzet A, Cottel D, et al. Association between a thyroid hormone receptor- $\alpha$ gene polymorphism and blood pressure but not with coronary heart disease risk. Am J Hypertens. 2011;24(9):1027-34. https://doi. org/10.1038/ajh.2011.94

PMid:21654857

6. Martınez E, Puras A, Escribano J, Sanchis C, Carrion L, Artigao $\mathrm{M}$, et al. Angiotensin-converting enzyme (ACE) gene polymorphisms, serum ACE activity and blood pressure in a Spanish-mediterranean population. J Hum Hypertens. 2000;14(2):131-5. https://doi.org/10.1038/sj.jhh.1000958 PMid: 10723120

7. Okumuş $S$, Demiryürek Ş, Özkur M, Coşkun E, Tatar MG Erbağci $\mathrm{l}$, et al. No major impact of insertion/deletion polymorphism of the angiotensin-converting enzyme gene on thyroid-associated ophthalmopathy. Turkish J Med Sci. 
2013;43(3):436-40. https://doi.org/10.3906/sag-1207-113

8. Hernando VU, Eliana MS. Endocrinology and metabolic syndrome. Endocrinol Metab Synd. 2015;4(2):661-9.

9. Rivolta CM, Olcese MC, Belforte FS, Chiesa A, GruneiroPapendieck L, lorcansky S, et al. Genotyping of resistance to thyroid hormone in South American population. Identification of seven novel missense mutations in the human thyroid hormone receptor beta gene. Mol Cell Probes. 2009;23(3-4):148-53. PMid:19268523

10. Klein I, Danzi S. Thyroid disease and the heart. Circulation. 2007;116(15):1725-35 PMid:17923583

11. Canaris GJ, Manowitz NR, Mayor G, Ridgway EC. The colorado thyroid disease prevalence study. Arch Intern Med. 2000;160(4):526-34. https://doi.org/10.1001/archinte.160.4.526 PMid:10695693

12. Danzi S, Klein I. Thyroid hormone and blood pressure regulation. Curr Hypertens Rep. 2003;5(6):513-20.

PMid:14594573

13. Jeunemaitre X, Bassilana F, Persu A, Dumont C, Champigny G Lazdunski $\mathrm{M}$, et al. Genotype-phenotype analysis of a newly discovered family with Liddle's syndrome. J Hypertens. 1997;15(10):1091-100

PMid:9350583

14. Siyad AR. Hypertension. Hygeia J D Med. 2011;3(1):1-16.

15. Butler MG. Pediatric hypertension: Genetics of hypertension current status. J Med Liban. 2010;58(3):175-8.

16. Singh $K D$, Jajodia $A$, Kaur $H$, Kukreti $R$, Karthikeyan $M$. Gender specific association of RAS gene polymorphism with essential hypertension: A case-control study. Biomed Res Int. 2014;2014:538053. https://doi.org/10.1155/2014/538053 PMid:24860821

17. Singh M, Singh AK, Singh S, Pandey P, Chandra S, Gambhir IS et al. Angiotensin-converting enzyme gene I/D polymorphism increases the susceptibility to hypertension and additive diseases : A study on North Indian patients. Clin Exp Hypertens. 2016;38(3):305-11. https://doi.org/10.3109/10641963.2015.110 7085

PMid:27030424

18. Niu W, Qi Y, Cen W, Cui C, Zhuoma C. Genetic polymorphisms of angiotensinogen and essential hypertension in a tibetan population. Hypertens Res. 2007;30(11):1129-37. https://doi. org/10.1291/hypres.30.1129 PMid:18250562

19. Singh $M$, Pandey $P$, Singh $A K$, Chandra $S$, Singh $K A$,
Gambhir IS. Molecular genetics of essential hypertension. Clin Exp Hypertens. 2016;38(3):268-77. https://doi.org/10.3109/106 41963.2015.1116543

PMid:27028574

20. Gupta S, Agrawal B, Goel R, Sehajpal PK. Angiotensinconverting enzyme gene polymorphism in hypertensive rural population of Haryana, India. J Emerg Trauma Shock. 2009;2(3):150. https://doi.org/10.4103/0974-2700.55323

PMid:20009302

21. Tchelougou D, Kologo JK, Karou SD, Yaméogo VN, Bisseye C, Djigma FW, et al. Renin-angiotensin system genes polymorphisms and essential hypertension in Burkina Faso, West Africa. Int J Hypertens. 2015;2015:979631. https://doi. org/10.1155/2015/979631

PMid:26351579

22. Rasyid H, Bakri S, Yusuf I. Angiotensin-converting enzyme gene polymorphisms, blood pressure and pulse pressure in subjects with essential hypertension in a South Sulawesi Indonesian population. Acta Med Indones. 2012;44(4):280-3.

PMid:23314967

23. Krishnan R, Sekar D, Karunanithy S, Subramanium S. Association of angiotensin converting enzyme gene insertion/ deletion polymorphism with essential hypertension in south Indian population. Genes Dis. 2016;3(2):159-63. https://doi. org/10.1016/j.gendis.2016.03.001

PMid:30258884

24. Olateju TO, Vanderpump MP. Thyroid hormone resistance. Ann Clin Biochem. 2006;43(6):431-40. https://doi. org/10.1258/000456306778904678

PMid:17132274

25. Rebaï M, Kallel I, Rebaï A. Genetic features of thyroid hormone receptors. J Genet. 2012;91(3):367-74. https://doi.org/10.1007/ s12041-012-0179-x

PMid:23271024

26. Goumidi L, Flamant F, Lendon C, Galimberti D, Pasquier F, Scarpini E, et al. Study of thyroid hormone receptor alpha gene polymorphisms on Alzheimer's disease. Neurobiol Aging. 2011;32(4):624-30. https://doi.org/10.1016/j. neurobiolaging.2009.04.007

PMid:19427062

27. Sørensen HG, Van Der Deure WM, Hansen PS, Peeters RP, Breteler MM, Kyvik KO, et al. Identification and consequences of polymorphisms in the thyroid hormone receptor alpha and beta genes. Thyroid. 2008;18(10):1087-94. https://doi.org/10.1089/ thy.2008.0236

PMid: 18844476 